to that initial material, and it is hoped that additional collections will be brought in by a forthcoming expedition to Peru under Dr. Newell's leadership. Besides Palæozoic assemblages, to be studied and published separately, most of those collections are of Mesozoic age. The work of description is being divided among several specialists. So far, Dr. Raymond E. Peck and Mr. Reker have just finished a report on charophytes from various regions and horizons, intended for publication in the American Museum Novitates, Dr. John W. Wells will study the Anthozoa and Porifera, Dr. Newell has taken charge of the pelecypods, and Dr. Kummel will concentrate on Triassic cephalopods. Dr. Haas is studying the Post-Triassic cephalopods and the gastropods. Some important groups, especially the brachiopods, which are second only to the molluses in number of specimens, are still waiting for specialists to undertake their study. The Instituto Geológico del Peru, the director of which is Dr. Jorge Broggi, is co-operating with the American Museum of Natural History in all this work.

\section{Royal Commission for the Exhibition of 1851 : Overseas Scholarships 1947}

The Commissioners of the Royal Commission for the Exhibition of 1851 announce the award of Overseas Science Research Scholarships for 1947 to the following, the recommending body appearing in brackets : E. Gorham (Dalhousie University, Halifax), for research in plant ecology at University College, London; W. A. Bryce (McGill University, Montreal), for research in physical chemistry at the University of Oxford ; C. C. Costain (University of Saskatchewan), for research in physics at the University of Cambridge; D. R. Bowes (University of Adelaide), for research in geology at the Imperial College of Science and Technology, London; L. Riddiford (University of Melbourne), for research in physics at the University of Birmingham, or the University of Manchester; Miss June Lascelles (University of Sydney), for research in biochemistry at the University of Oxford ; J. N. Dodd (University of New Zealand), for research in physics at the University of Birmingham; J. P. Teegan (National University of Ireland), for research in physical chemistry at the University of Cambridge; Dr. A. K. Saha (University of Calcutta), for research in physics at the University of Birmingham; Dr. A. B. Bhatia (University of Allahabad), for research in physics at the University of Bristol.

\section{Leverhulme Research Fellowships : Awards for 1947}

THE following awards, among others, for research in the subject mentioned and tenable for periods up to two years, have been announced by the trustees of the Leverhulme Research Fellowships: Fellowships : R. C. Abraham, late district officer, Nigeria, modern languages of Ethiopia and Eritrea (renewal); Dr. R. Dennell, reader in experimental zoology, University of Manchester, structure and physiology of the luminous organs of the Decapoda; J. A. Ratcliffe, lecturer in physics, University of Cam. bridge, propagation of radio waves; Dr. $R$. Stoneley, lecturer in mathematics, University of Cambridge, elastic yielding of the earth. Research Grants: Dr. P. Allen, demonstrator in geology, University of Cambridge, comparative petrology and palæoecology of the European 'Wealden'; J. S. Barlee, biology master, Royal Naval College, Dartmouth, investigation into the status of certain birds in Ireland; Miss E. M. Brown, lecturer in zoology, Chelsea Polytechnic, London, parasitic dinoflagellates and other causal organisms of disease in fish; Dr. J. G. D. Clark, lecturer in archæology, University of Cambridge, economic and social prehistory of Europe since late Glacial times; J. S. Gittins, principal, Aycliffe Approved School, Darlington, a survey of the mental characteristics of delinquent boys; Dr. $J$. Grant, medical officer of health, County Borough of Gateshead, a study of epidemic diphtheria; Dr. F. R. Irvine, administrative officer, Faculty of Science, University of Edinburgh, indigenous plants of West Africa and their utilization for local purposes ; P. Slater, principal research officer, Social Survey, use of statistical methods in forecasting human behaviour. Information in connexion with Lever. hulme awards can be obtained from the Secretary, Leverhulme Research Fellowships, 7 Bedford Row, London, W.C.1.

\section{The Night Sky in August}

Full moon occurs on August 2d. 01h. 50m. U.T. and new moon on August 16d. 11h. $12 \mathrm{~m}$. The following conjunctions with the moon take place: August 12d. 22h., Mars. $2^{\circ}$ S. ; August 15d. 10h., Mercury $4^{\circ} \mathrm{S}$; ; August $22 \mathrm{~d}$. $18 \mathrm{~h}$., Jupiter $0 \cdot 1^{\circ} \mathrm{N}$. In addition to these conjunctions with the moon, Mercury is in conjunction with Jupiter on August 18d. 13h., Mercury being $0 \cdot 6^{\circ} \mathrm{N}$. Mercury rises $\mathrm{Ih}$. $22 \mathrm{~m}$. before the sun on August 1, but will not be an easy object to observe. It attains its greatest western elongation on August 3, and at the end of the month is a morning star, rising only 10 minutes before the sun. Venus rises 50 minutes before the sun on August 1 and practically at sunrise on August 31, and will not be well placed for observation during the month. Mars, in Gemini, is visible in the early morning hours, rising soon after midnight during most of the month. Jupiter, in the constellation of Libra, is visible in the early portion of the night, setting at $23 \mathrm{~h}$. and $21 \mathrm{~h} .06 \mathrm{~m}$. at the beginning and end of the month, respectively. Saturn, in conjunction with the sun on August 5, cannot be seen. The following occultations of stars brighter than magnitude 6 take place : August 14d. 03h. 21.5m., $A$ Gemi. $(R)$; August 24d. 20h. 29.0m., $88 B$ Ophi. $(D) . \quad R$ and $D$ refer to reappearance and disappearance, respectively, and the latitude of Greenwich is assumed. The Perseid shower of meteors attains its maximum about August 10-12; the radiant is close to R.A. 3h., Dec. $+57^{\circ}$.

\section{Announcements}

THE opening on July 14 of an Exhibition at the Science Museum, South Kensington, arranged with the Chemical Society, the eleventh International Congress of Pure and Applied Chemistry and the Department of Scientific and Industrial Research to illustrate the achievements of British chemists during the past century and to show the uses of chemistry in everyday life, marked the beginning of the centenary celebrations of the Chemical Society. The exhibition is now available to the general public, and will remain open until September 30 (weekdays, including August Bank Holiday, 10 a.m.-6 p.m.; Sundays, 2.30 p.m.-6 p.m.).

Dr. Adrien Albert, who for the last nine years has been working at the University of Sydney on the physics and chemistry of drug action, has joined the staff of the Wellcome Research Institution, London, to initiate similar studies there. 